\title{
Surveying Library Needs of the Office of Education
}

\author{
Mr. Dunbar is chief, Service to Libraries, \\ United States Office of Education.
}

\begin{abstract}
A A WELL-KNOWN UNIVERSITY, stu1 dents used to say irreverently that its medical center did not seem to care what happened to the patient; it was concerned, so they felt, only with whether or not the diagnoses and techniques used were correct. To some extent, this account will deal with only the techniques and methods used in a particular survey, and will not go into the fate of the "patient." The procedures developed will have significance and possible application, it is hoped, for any library with research responsibilities.
\end{abstract}

The occasion for this survey arose when the Library Committee of the Department of Health, Education, and Welfare attempted to define the function and scope of the Department Library. The different constituent units which compose the Department had diverse views regarding the services that should be required. To obtain facts for stating the Office of Education position, this inquiry about the needs of its staff for library facilities and services was undertaken.

\section{BACKGROUND INFORMATION}

By way of background, several pertinent facts should be borne in mind. The organic act of 1867 establishing the Office of Education, authorized the following:

Collecting such statistics and facts as shall show the condition and progress of education in the several States and Territories and diffusing such information ... as shall aid the people of the United States in the establishment and maintenance of efficient school systems, and otherwise promote the cause of education throughout the country.

In a recent article, Commissioner Brownell emphasized that the basic responsibilities laid upon the Office of Education by the enabling act of 1867 still hold and that one of these purposes is educational research.

\section{Objectives of the Survey}

A study of the objectives of the proposed survey by the Office of Education representatives revealed quickly that a statistical count of the use of the library was not enough. Several other dimensions were needed for a complete picture of the situation. Consequently, an inquiry schedule was devised which sought to ascertain from the education specialists :

(I) What types of materials are needed?

(2) For what purposes are they used?

(3) How frequently are they used?

In other words, some qualitative factors as well as quantitative ones were injected into the inquiry.

Allied to these three major questions, some other significant information was looked for, such as:

Subject areas covered by the Office of Education staff

Particular aspects of these subject areas on which the specialists concentrated

Need (expressed in terms of years) for back files of professional journals, association proceedings, college catalogs, annual reports, etc.

Professional books and journals that each 
specialist considered essential to his research or consultative services.

Availability of personal books and periodicals that might obviate the necessity of using the Department Library

Hindrances to research and consultative services because of inadequate library services and facilities

Assistance to research and consultative services because of satisfactory library services and facilities

\section{Types of Library Materials}

The first task in constructing the inquiry schedule was the compilation of a checklist of the types of materials that specialists in the field of education might be expected to use in their research and consultative services. This list was based on the Library of Congress classification schedules, on annual and other reports of the Office of Education Library, on publications in the field of education, and on suggestions from staff members.

After considerable adjustment and consolidation to facilitate ease in response, the following list of types of materials was drawn up:

\section{Special Collections in Education}

Theses

University and college catalogs

Courses of study

Periodicals, Domestic

Reports, State departments of education

Reports, Local school systems

Reports and proceedings, Education associations

Textbooks, Domestic

Statistics

\section{Foreign Collections in Education}

Annual reports of foreign ministries of education

Special reports of foreign ministries of education

Laws and regulations affecting education, Foreign

University catalogs, study plans, and examination regulations, Foreign
Journals issued by foreign university faculties and departments

School prospectuses, programs of study, Foreign

Annual reports of foreign chief executives to their legislative bodies

Proceedings of foreign educational associations

Periodicals, Foreign

Statistical yearbooks, Foreign

Textbooks, Foreign

Books, treatises, and monographs by foreign authors

\section{General Educational Subjects}

History of education

Philosophy of education

Theories and principles

Administration of schools

Adminstration of institutions of higher education

Curriculums and curriculum making

Finance, Schools

Finance, Institutions of higher education

Teaching

\section{Legal Literature}

Federal statutes

Bills, hearings, reports

Congressional Record

State laws

Other (specify)

Public Administration (excluding schools and colleges)

Fiscal management

Personnel management

Organization and management

Other (specify)

\section{General Reference}

(Such as encyclopedias, atlases, biographical dictionaries, etc.)

\section{General Cultural Subjects}

(Such as philosophy, sociology, fine arts, drama, travel, etc.)

\section{Purpose of Use}

Qualitative aspects of use are always difficult to measure. In this survey, an effort was made to find out not only what types of library materials were used, but also the 
reasons for which they were used. This list of purposes was compiled by identifying the characteristics of the various activities and tasks of the Office of Education personnel. It included the following categories:

Keeping up-to-date generally, seeking spot information

Answering letters

Preparing for field trips

Preparing magazine articles

Preparing talks or speeches

Work on projects that cannot be classified as research

Work on research projects

Work on administrative problems

Other (specify)

Never use

\section{Frequency of USE}

The next step was to inject the factor of frequency of use. After some consultations with the Research and Statistical Standards Section of the Office and with due recognition of the shortcomings of objective meas- ures which involve considerable subjectivity, the following scale of frequency with a code was drawn up so that respondents could indicate in the appropriate boxes how often they used the materials:

4: Very frequently used (at least 5 or 6 times a week)

3: Frequently used (about 2 or 3 times a week)

2: Occasionally used (about 2 or 3 times a month)

I: Seldom used (about 4 or 5 times a year or less)

o: Never use the Department Library for the material in question

The respondents were told that the term "use" includes: (a) in person; (b) by the secretary of the specialist; (c) by telephone; and (d) by automatic routing of materials from the Library.

To obtain facts about the types of materials used, the purposes of use, and the frequency of use, a form was devised, an item from which is reproduced here:

Purpose of Use

\begin{tabular}{|c|c|c|c|c|c|c|c|}
\hline \multirow[b]{2}{*}{$\begin{array}{l}\text { Type of } \\
\text { Material }\end{array}$} & \multirow[b]{2}{*}{$\begin{array}{l}\text { Never } \\
\text { use }\end{array}$} & \multirow[b]{2}{*}{$\begin{array}{l}\text { Keep up- } \\
\text { to-date } \\
\text { generally }\end{array}$} & \multirow[b]{2}{*}{$\begin{array}{l}\text { Prepare } \\
\text { letters }\end{array}$} & \multirow[b]{2}{*}{$\begin{array}{l}\text { Prepare } \\
\text { articles } \\
\text { or talks }\end{array}$} & \multicolumn{2}{|c|}{ Work on } & \multirow[b]{2}{*}{$\begin{array}{c}\text { Other } \\
\text { (Specify) }\end{array}$} \\
\hline & & & & & $\begin{array}{l}\text { Adminis- } \\
\text { trative } \\
\text { problems }\end{array}$ & $\begin{array}{l}\text { Research } \\
\text { projects }\end{array}$ & \\
\hline $\begin{array}{l}\text { Theses } \\
\text { Courses of study } \\
\text { Etc. }\end{array}$ & & & & & & & \\
\hline
\end{tabular}

Fields of Specialization*

\begin{tabular}{l|l|l|l}
\hline \hline \multicolumn{1}{c|}{ Aspects involved } & Field & Field & Field \\
\cline { 2 - 3 } Aims and objects & & & \\
Bibliography & & \\
Courses of study & & \\
Curriculum & & \\
History & & \\
Outlines, syllabi & & \\
Research & & \\
Statistics & & \\
Surveys & & \\
Teaching aids & & \\
Teaching methods & & \\
Textbooks & & \\
Units of work & & \\
Other (specify) & & \\
\hline
\end{tabular}

Each respondent was asked to indicate in the proper boxes how often and for what reasons he used the various types of library materials listed.

\section{Areas of Specialization}

In addition to asking for the fields of specialization of each Office of Education staff member, the questionnaire requested

* Enter name of major subject field at the head of the column under "Field." If respondent has more than one area of specialization, name each one at the head of one of the columns.

Enter frequency of use of materials for each aspect Enter frequency of use of materials for each aspect
nvolved in the column under the field in question. nvolved in the column under the field in question.
Code for frequency of use: Very frequently, frequently, 3 ; occasionally, 2 ; seldom, 1 ; never, 0 . 
facts about the particular aspects of that field on which the specialist concentrated, together with the frequency of such use. This information was solicited by a special section of the inquiry as shown.

\section{Additional Significant Information}

Other significant facts about the needs for library service were obtained by having the respondents indicate in specific terms (current only, 5 years, 10 years, etc.) their opinions regarding the usefulness of back files of professional journals, reports of state departments of education, proceedings of educational associations, college catalogs, textbooks, etc. Similarly, the specialists were asked to list at least three books and three professional journals they considered the most essential for their work. The resulting list supplied a tool for evaluating in part the adequacy of the Department $\mathrm{Li}$ brary in the field of education.

The inquiry form also called for a report on the number of professional books and periodicals, owned personally and available in the specialist's office or that of the branch or division. This item was intended to give a clue to the extent that private collections were obviating the need for services from the Department Library.

Finally, the staff of the Office of Education was requested to express its judgment with substantiating facts on (a) the lacks in services or facilities of the Department Library and (b) the satisfactory services and facilities of the Department Library.

\section{Methods Used}

The original intention was to use the in- terview method in obtaining the desired information from the Office of Education staff. The time required for this procedure and the difficulty of fixing convenient times for interviews with a busy staff led to an abandonment of that idea. Accordingly, the questionnaire was simplified, explanations added, and try-outs made on a small group of staff members.

The revised questionnaire was then sent, with an accompanying letter from Commissioner S.M. Brownell, to educational specialists, statisticians, editorial personnel, special assistants, and administrative workers in the Office of Education. The commissioner explained the purpose of the survey, and requested that the answers reflect the normal use of library materials by the respondent. He suggested further that the past year be used as a basis for the response if that year could be considered typical. The commissioner's letter also carried the names of the Office of Education representatives who would be available for additional explanations. In a number of cases, the questionnaire returns were supplemented by personal interviews.

As stated at the outset, this account has dealt only with the techniques and methods employed in a survey of the library needs of a specific federal agency with research responsibilities. The returns, however, were almost $100 \%$ and the data reported made possible some conclusions and recommendations regarding the met and unmet needs of the Office of Education personnel for library services and facilities. The procedures followed in solving the problems of this inquiry may have general application in similar situations.

\section{Ad Index}

The Advertisers Index has been omitted from this issue due to space limitations. 